\title{
Utilization of Online Oral Reading Test in Determining the Reading Skills of the Grade 6 Pupils in English
}

\author{
VERONICA G. NICOLAS 8 (D) \\ Teacher III of Padre Mariano Gomez Elementary School, Schools Division Office-Manila \\ $\triangle$ Corresponding Author: VERONICA G. NICOLAS, E-mail: veronica.nicolas@deped.gov.ph
}

\author{
ARTICLE INFORMATION \\ Received: March 08, 2021 \\ Accepted: April 22, 2021 \\ Volume: 3 \\ Issue: 4 \\ DOI: 10.32996/jweep.2021.3.4.1
}

\section{KEYWORDS}

Oral Reading Test, Reading Skills, Speed, Comprehension, Online platforms, Frustration, Instructional, independent

\section{ABSTRACT}

Reading is every child's foundation where great learning is involved and evidently proved one's comprehension. Reading teachers play a vital role in assessing their pupils' reading skills and administering intervention programs for learners' reading development. This action research employed the Phil-IRI (Philippine Informal Reading Inventory) Oral Reading Test. This is an informal measure that assesses the pupils' reading skills, both their reading speed and comprehension. It consists of graded reading passages from Grade I to Grade VI. Each graded passage is followed by 7 comprehension questions for Grades I-III and 8 comprehension questions for Grades IV-VI. The questions are categorized into three dimensions, namely literal, interpretive, and applied. Hence, reading speed and comprehension of the pupils will be classified into three levels as frustration, instructional and independent with the applied criteria given by the Phil-IRI. Furthermore, the results of the study exhibited that the ten groups of pupils demonstrated low reading performance in their oral reading test both in speed and comprehension. The struggle of the online oral reading test was evidently shown through the weak internet connection provided by the internet servers in the country. With this, the researcher designed a reading intervention program through reading remedial class during asynchronous class. This will be administered using the online platform and available reading resources for the enhancement of pupils' reading skills amidst these trying times of global pandemic, where distance learning has been practised first in the public schools' setting in the Philippines.

\section{Introduction}

Reading skill refers to the ability to understand written text. When learners comprehend and understand written text and combine it with prior knowledge, they are able to perform comprehension skills (Tadesse 2017). This emphasizes the importance of reading as an indispensable tool to improve pupils' learning skills. It is the foundation on which the academic skills of the pupil are built and developed through various studies and training. Amidst this pandemic, huge challenges occur in our field of education. Fortunately, teachers will be utilizing online teaching platforms to impart valuable knowledge and continue the Department of Education (DepEd) advocacy to make every Filipino child a reader at his/her grade level (DepEd Order No 12, s. 2015).

This school year, when pandemic tests our country due to COVID-19, online teaching and learning platforms have been offered through distance learning. Nevertheless, the struggle is real. According to Amadora in her article (Manila Bulletin published September 18, 2020), she cited the common problems that occur during online class: weak internet connection, audio clarity, outdated device and software, system glitch, and learners' short attention span. Indeed, $21^{\text {st }}$-century teachers take the challenge of using different online platforms to conduct an oral reading test with many initiatives, determination and commitment for pupils' reading enhancement.

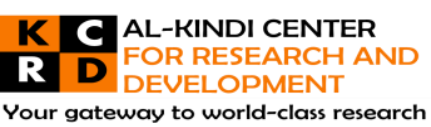

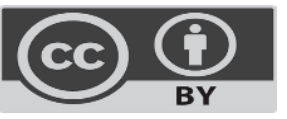

Published by Al-Kindi Center for Research and Development. Copyright (c) the author(s). This open access article is distributed under a Creative Commons Attribution (CC-BY) 4.0 license 


\section{Significance of the Study/Rationale}

The results of this study are essential to English Teachers; this research will provide online teaching strategies in administering an oral reading test. The reading teachers in English utilize different online platforms through video conferencing with the use of Google Meet, Zoom, MS Teams and alike.

Hence, School Administrators will be encouraged to provide teachers with valuable seminars, training, and workshops on online platforms and interactive computer applications to cater to reading assessment and offer new teaching competencies, strategies, techniques, and approaches in teaching online.

Parents will also be benefited from this action research; this research intensifies their role as the support system of their children to guide them in attending online reading remedial class and do follow-ups in teaching their children to read. Future researchers will benefit from this action research; this research will challenge them to administer online oral reading tests and other reading assessments despite the hindrances of this pandemic.

\section{Research Problems/Questions}

The research sought to answer the following specific questions:

1. What is the importance of an oral reading test?

2. How does online oral reading test contribute to the administration of reading assessment?

3. What are the possible problems to be encountered during the online reading test?

4. What is the reading skill of Grade 6 pupils both in reading speed and level of comprehension?

\section{Methodology}

This research endeavors utilized a quantitative method. This study was anchored in the Oral Reading Test of the Philippine Informal Reading Inventory. The Philippine Informal Reading Inventory (Phil-IRI) initiative of the Bureau of Learning Delivery, Department of Education, directly addresses its thrust to make every Filipino child a reader. It is the flagship program of the Department: "Every Child A Reader Program," from DepEd Order No.12, series of 2015, which aims to make every Filipino child a reader and a writer at his/her grade level. The pupils were given a passage intended for an oral reading test from the Phil-IRI to assess learners' reading skills both on speed and comprehension skills. It is composed of a graded reading passage with eight comprehension questions for intermediate learners.

\subsection{Participants/Data Source}

The study made use of the Grade 6 pupils of P. Gomez Elementary School from Schools Division Office-Manila as subjects, currently enrolled this school year 2020-2021, as the researcher is one of the faculty members of the said grade level. Among the five sections handled by the researcher, this class was selected using the convenience sampling technique.

The researcher included the mentioned subjects composed of 40 pupils who took part in the study. They were grouped into 10 , with 4 members in each group. In addition, they were assessed regardless of their gender and age to carefully evaluate their reading skills in English via Google Meet.

\subsection{Data Gathering Procedure/Instrument}

To assess the pupils' reading skills, the researcher utilized the Phil-IRI Oral Reading Test that gives quantitative information about the pupil's oral reading capabilities with a predetermined set of criteria to identify the pupils' reading levels as the reading speed and percentage of correct answers to comprehension questions. These criteria include the percentage of word recognition accuracy and the percentage of correct answers to comprehension questions (adapted from Johnson, Kress and Pikulski, 1987).

The researcher recorded the time that the pupil starts reading the passage orally. This followed by computing the number of seconds that it took the pupil to read the passage divided by the number of words of the passage, then multiplied by 60 equals to word per minute. In the 2012 Phil-IRI manual, the criteria on the reading speed were set into three levels based on the grade levels. Grade 6 level reading speed based on a word per minute will be classified into three: a fast reader (independent level) obtains 190 above, an average reader (instructional level) has 161-169 and slow reader (frustration level) acquires 160 and below word per minute (WPM).

In addition, the researcher also documented the miscue on the mispronunciation of the words committed by each pupil. The computation of the oral reading score involves counting the number of miscues minus the number of words divided by the number of words to be multiplied by 100 . On the analysis and interpretation of word reading in per cent, the pupils' reading level will be categorized into three: $97-100 \%$ independent level at which readers function on their own with almost perfect oral 
reading and excellent comprehension (Flippo,2014), 90-96\% instructional level at which readers profit the most from teacherdirected instruction in reading (Flippo, 2014 ), and $89 \%$ and below frustration level at which readers find reading materials so difficult that they cannot successfully respond to them (Flippo,2014). On computing the pupil's comprehension of the passage after the pupil has read the passage, the teacher reads the comprehension questions and records the pupil's responses. The comprehension level is computed by using the formula of a number of correct answers divided by the number of questions multiplied by 100 equals the percentage of the score. The scores in (\%) will be classed into three levels: $80-100 \%$ independent, $59-79 \%$ instructional and 58 and below is frustration.

On the other hand, the researcher administered the online survey that includes their gadget or device and the internet provider they used to know the pupils' problems during the online oral reading test.

At the end of the research, we will be able to know the reading skills of the pupils through interpreting the data results accumulated from the online platforms using Google Meet and Google Forms.

\subsection{Data Analysis}

The gathered data were subjected to statistical treatment to determine the pupils' reading skills and the problems they faced during the online oral reading test amidst this pandemic.

The summary of the data on the pupils' reading skill was grouped into three: oral reading performance (no. of miscues), reading speed and comprehension level. The data also included the types of available gadget/device used by the pupils and the problems during the online reading test. The collected data were treated using the following statistical tools i.e., frequency, percentage and ranking.

\section{Results and Discussions}

Analysis and interpretation of the gathered data were summarized in the following tables.

Table 1. Frequency and Percentage of Grade 6 Pupils' Oral Reading Level Based on the Number of Miscues (Mispronounced Words)

\begin{tabular}{|c|c|c|c|}
\hline Group & Frequency & Percentage & Interpretation \\
\hline 1 & 10 & 92.80 & Instructional \\
\hline 2 & 13 & 90.64 & Instructional \\
\hline 3 & 5 & 96.40 & Instructional \\
\hline 4 & 12 & 91.36 & Instructional \\
\hline 5 & 7 & 94.96 & Instructional \\
\hline 6 & 6 & 95.68 & Instructional \\
\hline 7 & 8 & 94.24 & Instructional \\
\hline 8 & 10 & 92.80 & Instructional \\
\hline 9 & 8 & 94.24 & Instructional \\
\hline 10 & 7 & 94.96 & \\
\hline
\end{tabular}

The accumulated miscues per group are presented in Table 1. Group 3 obtains 5 miscues as the least number of mispronounced words with 96.40 per cent as classified instructional or the level at which readers profit the most from teacher-directed instruction in reading. However, Group 2 acquires the highest number of miscues with 13 or 90.64 per cent. On the other hand, Groups 1-10 are under the instructional level based on Phil-IRI Oral Reading Profile criteria with a reading score of 90-96 per cent. 
Table 2. Reading Speed Level of Grade 6 Pupils in Online Oral Reading Test

\begin{tabular}{|c|c|c|c|}
\hline Group & Total Word Per Minute & Level & Interpretation \\
\hline 1 & 110 & Slow Readers & Frustration \\
\hline 2 & 138 & Slow Readers & Frustration \\
\hline 3 & 139 & Slow Readers & Frustration \\
\hline 4 & 139 & Slow Readers & Frustration \\
\hline 5 & 139 & Slow Readers & Frustration \\
\hline 6 & 139 & Slow Readers & Frustration \\
\hline 7 & 139 & Slow Readers & Frustration \\
\hline 8 & 139 & Slow Readers & Frustration \\
\hline 10 & 121 & Slow Readers & Slow Readers \\
\hline
\end{tabular}

In terms of reading speed, the groups' total score word per minute falls under frustration level or pupils are classified as slow readers based on the Phil-IRI criteria on reading speed. Thus, readers in frustration level or slow readers render 160 and below word per minute.

Table 3. Reading Comprehension Level of Grade 6 Pupils in Online Oral Reading Test

\begin{tabular}{|c|c|c|c|}
\hline Group & Total Scores & Percent & Interpretation \\
\hline 1 & 4 & 50 & Frustration \\
\hline 2 & 5 & 63 & Frustration \\
\hline 3 & 3 & 38 & Frustration \\
\hline 4 & 4 & 50 & Frustration \\
\hline 5 & 5 & 63 & Frustration \\
\hline 6 & 4 & 50 & Frustration \\
\hline 7 & 4 & 50 & Frustration \\
\hline 8 & 5 & 63 & Frustration \\
\hline 9 & 4 & 50 & Frustration \\
\hline 10 & 4 & 50 & \\
\hline
\end{tabular}

Table 3 presents the reading comprehension level of each group. Groups 2, 5 and 8 demonstrate the highest accumulated score of 5 from 8 comprehension questions asked by the researcher after reading the passage. However, this signifies that the level of comprehension is frustration at which readers find reading materials so difficult that they cannot successfully respond to them. 
Table 4. Frequency and Percentage of Gadget/Device Utilized by the Grade 6 Pupils during the Online Oral Reading Test

\begin{tabular}{|c|c|c|c|}
\hline Gadget/Device & Frequency & Percentage & Rank \\
\hline smart phones & 22 & 55 & 4.5 \\
\hline own learning tablet & 1 & 32.5 & 2 \\
\hline $\begin{array}{c}\text { learning tablets (funded by } \\
\text { LGU -Manila, Mayor Isko } \\
\text { Domagoso) }\end{array}$ & 13 & 2.5 & 4.5 \\
\hline laptop & 1 & 7.5 & 3 \\
\hline Total & 40 & 100 & \\
\hline
\end{tabular}

The data gathered from tables 4, 5 and 6 arrived from the survey conducted by the researcher using Google Forms and automatically recorded with individual responses. Hence, table 4 above reveals that the pupils have available gadgets like smartphones with 22 or 55 per cent, followed by 13 or 32.5 per cent learning tablets. This shows that pupils have the capacity to participate in the oral reading test with the available resources such as smartphones and learning tablets.

Table 5. Frequency and Percentage of Internet Providers utilized by the Grade 6 Pupils during the Online Oral Reading Test

\begin{tabular}{|c|c|c|c|}
\hline Source of Internet connection & Frequency & Percentage & Rank \\
\hline Freeload data (10G monthly funded by LGU & 19 & 47.5 & 1 \\
\hline own mobile data & 6 & 7.5 & 4 \\
\hline prepaid Wi-Fi broadband & 3 & 30 & 2 \\
\hline unlimited Wi-Fi broadband Total & 40 & 100 & \\
\hline
\end{tabular}

Table 5 reveals the sources of internet connection. The monthly accessible data load funded by Manila LGU has been an excellent assistance for the pupils to participate in the online reading test with 19 or 47.5 per cent. Rank 2 on the list with 12 or 30 per cent, those pupils have their own Wi-Fi connection at home.

Table 6. Frequency and Percentage of the Encountered Problems during Online Oral Reading Test

\begin{tabular}{|c|c|c|c|}
\hline Online Problem & Frequency & Percentage & Rank \\
\hline weak internet connection & 19 & 47.5 & 4.5 \\
\hline outdated gadget & 1 & 2.5 & 3 \\
\hline noise distraction & 2 & 5 & 2.5 \\
\hline lack of data load & 1 & 42.5 & 2 \\
\hline none & 17 & 100 & \\
\hline
\end{tabular}


Results show that the weak internet connection with 19 or 47.5 percent displays the common problem encountered during the online reading assessment. However, due to reading assessment, the pupils managed to stay quiet; they did not meet any hindrances throughout the reading process with 17 or 42.5 per cent.

Based on the presented results of the study, the researcher designed a weekly block plan for February to administer a onemonth reading remedial class for the pupils under frustration level. This weekly block plan is composed of the reading skills to be augmented by providing online reading drills or exercises, audio lessons and video lessons that may enhance the pupils' reading skills both in reading speed and comprehension level. The researcher also found out that miscues fall under the mispronunciation of words with silent letters. This encouraged the researcher to target reading skills to recognise words with silent letters for the remedial reading class. The sample weekly block plan for implementing the reading intervention program on the administration of the remedial class is presented to highlight the reading activities to be facilitated by the reading teacher.

\section{WEEKLY BLOCK PLAN IN READING INTERVENTION PROGRAM Week 1 (February 01-05, 2021)}

\begin{tabular}{|c|c|c|c|c|c|}
\hline WEEK 1 & February 01 & February 02 & February 03 & February 04 & February 05 \\
\hline SKILL & \multicolumn{5}{|c|}{ Recognition of words with silent letters } \\
\hline MODALITY & \multicolumn{2}{|c|}{ Synchronous Class } & \multicolumn{3}{|c|}{ Asynchronous Class } \\
\hline STRATEGIES & $\begin{array}{r}\text { Video Confere } \\
\text { Regular o } \\
\text { (Da }\end{array}$ & $\begin{array}{l}\text { ig via Google } \\
\text { teaching } \\
-2)\end{array}$ & $\begin{array}{l}\text { Video } \\
\text { Conferencing via } \\
\text { Google Meet to } \\
\text { tackle the ff: } \\
\text { 1. Set the } \\
\text { schedule for } \\
\text { remedial class } \\
\text { (per group) } \\
\text { 2. Orientation } \\
\text { on the } \\
\text { administration } \\
\text { of the remedial } \\
\text { reading class } \\
\text { with the parents }\end{array}$ & $\begin{array}{l}\text { Video } \\
\text { Conferencing } \\
\text { via Google } \\
\text { Meet to utilize } \\
\text { the ff: } \\
\text { 1. Video lesson } \\
\text { on the } \\
\text { recognition of } \\
\text { silent letters. } \\
\text { 2. Speech drill }\end{array}$ & $\begin{array}{l}\text { Upload a } \\
\text { softcopy of the } \\
\text { silent letters' } \\
\text { exercises from } \\
\text { words to } \\
\text { phrases, then } \\
\text { phrases to } \\
\text { sentences, } \\
\text { finally } \\
\text { sentences to } \\
\text { simple } \\
\text { paragraphs } \\
\text { through } \\
\text { Facebook } \\
\text { messenger. }\end{array}$ \\
\hline ASSESSMENT & $\begin{array}{l}\text { NF2F: Virtual } \\
\text { process } \\
\text { evaluation }\end{array}$ & $\begin{array}{l}\text { NF2F: } \\
\text { Virtual } \\
\text { process } \\
\text { evaluation }\end{array}$ & $\begin{array}{l}\text { NF2F: Learner } \\
\text { or parent may } \\
\text { have full } \\
\text { coordination } \\
\text { with the reading } \\
\text { teacher. }\end{array}$ & $\begin{array}{l}\text { NF2F: Virtual } \\
\text { process } \\
\text { evaluation } \\
\end{array}$ & $\begin{array}{l}\text { NF2F: } \\
\text { Learner's } \\
\text { reading skill } \\
\text { will be } \\
\text { assessed on } \\
\text { virtual remedial } \\
\text { class. }\end{array}$ \\
\hline
\end{tabular}

\section{Conclusions and Recommendations \\ 6.1 Summary of Findings}

The researcher arrived at the following conclusions from the analysed and interpreted data: The ten groups of pupils demonstrated low reading performance in their oral reading test both in speed and comprehension. The struggle of the online oral reading test was evidently shown through weak internet connection wherein the researcher reset the schedule of the oral reading test due to an experienced signal problem, thus slowing down the assessment process. However, the willingness of the pupils to participate in any learning opportunities like this oral reading test had thrived well through the initiative of the Local Government Unit (LGU) spearheaded by the City Mayor of Manila, Mayor Isko Domagoso. His commendable support for the SDO Manila was remarkable by providing the learners both in elementary and secondary levels the learning tablets per 
household with a data allowance of $10 \mathrm{G}$ monthly load to ensure quality education will be delivered through distance learning amidst this global pandemic. This had shown a great contribution for the success of this study.

\subsection{Implication/Reflections and Recommendations}

Based on the findings of this research, the following recommendations were crafted: First, administrators should have full coordination with the school heads, teachers, parents, and pupils in the administration of the online reading test to assess the reading performance of the learners which the importance of reading as the foundation of all learning will be given much priority. Second, to effectively enhance the pupils' reading skills, interactive online reading workshops, training and webinars may be provided for the teachers to adopt effective reading strategies in this virtual learning. Third, the reading teachers should promote the utilization of various online reading strategies, methods, and approaches by which pupils improve their reading performance through reading intervention program designed by their respective schools. Fourth, parents play a vital role in guiding their children in the teaching and learning process. They are the teaching facilitators of their children. With their full cooperation to enhance their children's reading skills, they must continue to administer reading time at home during their children's asynchronous class using the reading materials provided by the reading teachers. Lastly, further studies with regards to the efficiency of the designed and utilized online reading intervention program will be administered to assess the pupils' reading progress and continue the stakeholders' immense support to the advocacy of the Department of Education to make every Filipino child a reader.

\section{References}

[1] Amadora, M. (2020). Common Problems that Occur During Online Classes. Retrieved from: https://mb.com.ph/2020/09/18/commonproblems-that-occur-during-online-classes

[2] Flippo, R. (2014). Assessing readers qualitative diagnosis and instruction. 2nd Edition. Chapter2 Retrieved from: http://www.reading.org/Libraries/books/assessing-

[3] readers--second-d--chapter3.

[4] Philippine Informal Reading Inventory Manual (Phil-IRI) (2018). Department of Education -Bureau of Learning Resources (DepEd-LR), DepEd ComplexMeralco Avenue, Pasig City, Philippines

[5] Philippine Informal Reading Inventory Manual (Phil-IRI) (2012). Department of Education -Bureau of Learning Resources (DepEd-LR), DepEd ComplexMeralco Avenue, Pasig City, Philippines

[6] Tadesse, T. (2017). Re: What is reading skill and its significance? Retrieved from: https://www.researchgate.net/post/what_is_reading_skill_and_its_significance

[7] The Department of Education (DepEd) Retrieved from: https://www.deped.gov.ph/2017/04/19/do-18-s-2017-guidelines-on-the-utilizationof-the-2017-every-child-a-reader-program-funds-for-the-early-language-literacy-and-numeracy-program-professional-development component 